\title{
Determination of the uptake and translocation of nitrogen applied at different growth stages of a melon crop (Cucumis melo L.) using ${ }^{15} \mathrm{~N}$ isotope
}

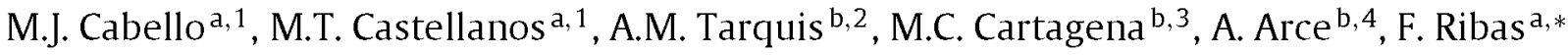 \\ a Centro Agrario El Chaparrillo, Delegación Provincial Agricultura y Medio Ambiente, C/Alarcos, 21, 13071 Ciudad Real, Spain \\ ${ }^{\mathrm{b}}$ Escuela Técnica Superior de Ingenieros Agrónomos, Universidad Politécnica, Ciudad Universitaria sn, 28040 Madrid, Spain
}

Keywords:

Cucumis melo

Dry matter

N distribution

${ }^{15} \mathrm{~N}$-labelled

N uptake

N translocation

\begin{abstract}
A B S T R A C T
In order to establish a rational nitrogen $(\mathrm{N})$ fertilisation and reduce ground water contamination, a clearer understanding of the $\mathrm{N}$ distribution through the growing season and its dynamics inside the plant is crucial. In two successive years, a melon crop (Cucumis melo L. cv. Sancho) was grown under field conditions to determine the uptake of $\mathrm{N}$ fertiliser, applied by means of fertigation at different stages of plant growth, and to follow the translocation of $\mathrm{N}$ in the plant using ${ }^{15} \mathrm{~N}$-labelled $\mathrm{N}$. In 2006 , two experiments were carried out. In the first experiment, labelled ${ }^{15} \mathrm{~N}$ fertiliser was supplied at the female-bloom stage and in the second, at the end of fruit ripening. Labelled ${ }^{15} \mathrm{~N}$ fertiliser was made from ${ }^{15} \mathrm{NH}_{4}{ }^{15} \mathrm{NO}_{3}$ (10 at.\% $\left.{ }^{15} \mathrm{~N}\right)$ and $9.6 \mathrm{~kg} \mathrm{Nha}^{-1}$ were applied in each experiment over 6 days $\left(1.6 \mathrm{~kg} \mathrm{~N} \mathrm{ha}^{-1} \mathrm{~d}^{-1}\right)$. In 2007 , the ${ }^{15} \mathrm{~N}$ treatment consisted of applying $20.4 \mathrm{~kg} \mathrm{~N}^{-1}$ as ${ }^{15} \mathrm{NH}_{4}{ }^{15} \mathrm{NO}_{3}\left(10 \mathrm{at} . \%{ }^{15} \mathrm{~N}\right)$ in the middle of fruit growth, over 6 days $\left(3.4 \mathrm{~kg} \mathrm{Nha}^{-1} \mathrm{~d}^{-1}\right)$. In addition, 93 and $95 \mathrm{~kg} \mathrm{Nha}^{-1}$ were supplied daily by fertigation as ammonium nitrate in 2006 and 2007, respectively. The results obtained in 2006 suggest that the uptake of $\mathrm{N}$ derived from labelled fertiliser by the above-ground parts of the plants was not affected by the time of fertiliser application. At the female-flowering and fruit-ripening stages, the $\mathrm{N}$ content derived from ${ }^{15} \mathrm{~N}$-labelled fertiliser was close to $0.435 \mathrm{~g} \mathrm{~m}^{-2}$ (about $45 \%$ of the $\mathrm{N}$ applied), while in the middle of fruit growth it was $1.45 \mathrm{~g} \mathrm{~m}^{-2}$ ( $71 \%$ of the $\mathrm{N}$ applied). The $\mathrm{N}$ application time affected the amount of $\mathrm{N}$ derived from labelled fertiliser that was translocated to the fruits. When the $\mathrm{N}$ was supplied later, the $\mathrm{N}$ translocation was lower, ranging between $54 \%$ at female flowering and $32 \%$ at the end of fruit ripening. Approximately $85 \%$ of the $\mathrm{N}$ translocated came from the leaf when the $\mathrm{N}$ was applied at female flowering or in the middle of fruit growth. This value decreased to $72 \%$ when the ${ }^{15} \mathrm{~N}$ application was at the end of fruit ripening. The ammonium nitrate became available to the plant between 2 and 2.5 weeks after its application. Although the leaf $\mathrm{N}$ uptake varied during the crop cycle, the $\mathrm{N}$ absorption rate in the whole plant was linear, suggesting that the melon crop could be fertilised with constant daily $\mathrm{N}$ amounts until 2-3 weeks before the last harvest.
\end{abstract}

\section{Introduction}

The melon crop occupies more than 40,000 ha in Spain, with a total production close to 1.2 million tonnes, mostly of the Piel de sapo type, making Spain the main European producer, with $48 \%$ of the total production in 2009 (FAOSTAT, 2010). The largest areas

\footnotetext{
* Corresponding author. Tel.: +34 926231401; fax: +34926229800. E-mail addresses: mjcabello@jccm.es (M.J. Cabello), mtcastellanos@jccm.es (M.T. Castellanos), anamaria.tarquis@upm.es (A.M. Tarquis), mariacarmen.cartagena@upm.es (M.C.Cartagena), augusto.arce@upm.es (A. Arce), fribas@jccm.es (F. Ribas).

1 Tel.: +34 926231401

2 Tel.: +34913365826

3 Tel.: +34913365649

4 Tel.: +34913363258
}

are concentrated in the southern half of the Iberian Peninsula and more than 12,000 ha are dedicated to this crop in Castilla-La Mancha, in the centre of Spain, which has a total production close to 365,000 tonnes (MARM, 2010).

In this area, current legislation requires farmers to adjust the supply of $\mathrm{N}$ to the requirements of the plants, to prevent nitrate losses and environmental problems. The amount and application time of fertiliser should be optimised according to the crop requirements at the different phenological stages and in accordance with the Good Agricultural Practices formulated by the Ministry of Agriculture, so that the environmental impact can be reduced, the fruit quality can increase, because the $\mathrm{N}$ excess produces lower flesh ratio and both higher skin ratio and percentage of placenta and seeds (Cabello et al., 2009) and also the cost of production can be reduced - increasing the $\mathrm{N}$ use efficiency (Gastal and Lemaire, 2002). 
Like other crops such as cucumber, melon plants have an indeterminate growth habit and develop new branches, flowers and fruits for a long time, until environmental conditions prevent further growth. In these crops, a proper $\mathrm{N}$ balance must be maintained, to obtain appropriate proportions of vegetative and reproductive parts (Tanemura et al., 2008; Castellanos et al., 2011). For this, information concerning the uptake and translocation by plants of $\mathrm{N}$ fertiliser applied at different times and the contribution of $\mathrm{N}$ to plant growth and fructification is vital for increasing crop yields through efficient use of $\mathrm{N}$ fertiliser. The importance of the leaf in the translocation of assimilates to the fruit has been reported in different crops like tomato (Scholberg et al., 2000), pepper (FangGong et al., 2002) or cucumber (Latus et al., 1995; Tanemura et al., 2008). However, in this respect, for melon the information is very scanty and in most cases the results are based on experiments conducted under greenhouse conditions and with different cultivars belong to Reticulatus (Fontes et al., 2003; Purqueiro et al., 2003) or Cantalupensis (Fagan et al., 2006).

Plant growth and fruit yield of melon depend on the $\mathrm{N}$ supply. This $\mathrm{N}$ may be necessary during the fruit-harvest period because the growth of leaves and stems continues together with setting, enlargement and ripening of the fruits. Therefore, it is necessary to study the $\mathrm{N}$ uptake dynamic and its translocation in the plant in order to optimise the fertilisation, because differences in soil characteristics, climate and crop management may significantly influence the results. Isotopic techniques based on ${ }^{15} \mathrm{~N}$ labelling have proved to be the most-effective means of measuring $\mathrm{N}$ fluxes between different tissues or organs, and for evaluating the respective contributions of $\mathrm{N}$ remobilised from storage tissues or recently acquired by uptake and fixation from the environment (Atta et al., 2004; Tanemura et al., 2008). Also, ${ }^{15} \mathrm{~N}$ studies can be used to quantify the percentage of $\mathrm{N}$ uptake by the plant that originates from fertiliser and how much comes from soil mineral N (Janat, 2007; Kotur et al., 2007; Latus et al., 1995; Lopez-Bellido et al., 2006). ${ }^{15} \mathrm{~N}$ isotopic technique is the only direct means of measuring nutrient uptake from applied fertiliser and can give results different to those obtained by indirect, classical methods (IAEA, 2001). Also, ${ }^{15} \mathrm{~N}$ studies can provide information about how long fertiliser $\mathrm{N}$ remains in the soil $\mathrm{N}$

The aims of this work were to quantify the uptake of $\mathrm{N}$ applied at different stages of plant growth (female flowering, growth and ripening of fruits), to determine the $\mathrm{N}$ distributed among the different aerial organs and its translocation from vegetative organs to the fruit and to determine the time that $\mathrm{N}$ fertiliser remains in the soil and is available for the crop, with respect to the time of application, using ${ }^{15} \mathrm{~N}$-labelled fertiliser.

\section{Materials and methods}

\subsection{Experimental site and climate data}

The experiment was carried out in Ciudad Real (Spain) during the May-September season in 2006 and 2007, in adjacent small fields, at the agricultural experimental research station "La Entresierra" ( $3^{\circ} 56^{\prime} \mathrm{W}-39^{\circ} 0^{\prime} \mathrm{N}, 640 \mathrm{~m}$ a.s.l.). The soil of this experimental site is a shallow sandy loam, classified as Alfisol Xeralf Petrocalcic Palexeralfs (Soil Survey Staff, 1999), with a depth of $0.60 \mathrm{~m}$, below which there is a fragmented petrocalcic horizon. The soil characteristics are provided in Table 1. The area is characterised by a continental Mediterranean climate, with widely fluctuating daily temperatures. The climatic data are given in Table 2. In the 2 years before the experiment, non-irrigated winter wheat (Triticum aestivum $\mathrm{L}$.) was grown on the plots, to which no organic matter or fertilisers were added.
Table 1

The physico-chemical properties of the soil $(0-15 \mathrm{~cm})$ at the field experimental sites in 2006 and 2007.

\begin{tabular}{lcc}
\hline Properties & 2006 & 2007 \\
\hline $\mathrm{pH}$ & 7.90 & 8.55 \\
Electrical conductivity $(\mathrm{mS} / \mathrm{cm})$ & 0.15 & 0.16 \\
Organic matter $(\mathrm{g} / \mathrm{kg})$ & 22.1 & 22.2 \\
Available $\mathrm{P}(\mathrm{mg} / \mathrm{kg})$ & 16.4 & 17.9 \\
Available $\mathrm{K}(\mathrm{mg} / \mathrm{kg})$ & 347.0 & 342.5 \\
Available $\mathrm{Ca}(\mathrm{mg} / \mathrm{kg})$ & 1811.8 & 2016.9 \\
Available $\mathrm{Mg}(\mathrm{mg} / \mathrm{kg})$ & 728.9 & 759.0 \\
Kjeldahl $\mathrm{N}(\mathrm{g} / \mathrm{kg})$ & 1.0 & 1.1 \\
\hline
\end{tabular}

\subsection{Crop management, experimental design and ${ }^{15} \mathrm{~N}$ treatment}

Seeds of 'Piel de sapo' melon (Cucumis melo L., var. inodorous, cv. Sancho) were germinated under greenhouse conditions in April and the seedlings were transplanted to the field, with a transparent plastic mulch, when they had two or three true leaves, on 24 May 2006 and 28 May 2007, with a density of 4444 plants ha $^{-1}$ (plant spacing $1.5 \mathrm{~m} \times 1.5 \mathrm{~m})$.

In 2006, two experiments with ${ }^{15} \mathrm{~N}$-labelled fertiliser were carried out: in the first, ${ }^{15} \mathrm{~N}$ fertiliser was applied from 22 June ( 29 days after transplanting (DAT)) to 27 June (34 DAT), starting five days after reaching the 4 stage (first perfect flower) according to the scale used by Baker et al. (2001), when $50 \%$ of plants had perfect flowers and the soil coverage by the crop was $65 \%$. In the second, ${ }^{15} \mathrm{~N}$ was supplied from 24 July (61 DAT) to 29 July (66 DAT), starting two days before the first harvest (5.4\% of the total yield) and when the soil coverage by the crop was $100 \%$. In each plot, $9.6 \mathrm{~kg} \mathrm{~N} \mathrm{ha}^{-1}$ were applied (1.6 kg N ha ${ }^{-1}$ per day). In 2007 , only one experiment was carried out, therefore the numbers of plant was lower and a greater amount of ${ }^{15} \mathrm{~N}$ could be supplied in order to amplify the changes in the ${ }^{15} \mathrm{~N}$ content in each organ. In this third trial, ${ }^{15} \mathrm{~N}$ was applied from 16 July (49 DAT) to 21 July (54 DAT), starting twenty-five days after reaching the 4 stage, seventeen days before the first harvest ( $8.9 \%$ of the total yield), and when the soil coverage by the crop was $80 \%$. In this period, $20.4 \mathrm{~kg} \mathrm{~N} \mathrm{ha}^{-1}$ were applied $\left(3.4 \mathrm{~kg} \mathrm{~N} \mathrm{ha}^{-1}\right.$ per day) in each plot.

Labelled ${ }^{15} \mathrm{~N}$ fertiliser was made from ${ }^{15} \mathrm{NH}_{4}{ }^{15} \mathrm{NO}_{3}\left(10\right.$ at.\% $\left.{ }^{15} \mathrm{~N}\right)$ and applied by fertigation. In the first experiment, the size of elemental plots was $3 \mathrm{~m} \times 12 \mathrm{~m}$ (16 plants) and $1.5 \mathrm{~m} \times 12 \mathrm{~m}$ (8 plants) in the second and third. In all cases, the experiments were arranged in a randomized complete blocks design with four replications.

Each plot row unit was irrigated by a dripping line with $0.5 \mathrm{~m}$ between drippers, each one of which provided $2 \mathrm{~L} \mathrm{~h}^{-1}$. In each year, plots were fertilised with $120 \mathrm{~kg} \mathrm{P}_{2} \mathrm{O}_{5} \mathrm{ha}^{-1}$ (as phosphoric acid), which was injected daily through the drip-irrigation system from three weeks after transplanting until the last week of August. The amounts of $\mathrm{N}$ supplied daily by fertigation as ammonium nitrate were $93 \mathrm{~kg} \mathrm{ha}^{-1}$ in 2006 and $95 \mathrm{~kg} \mathrm{ha}^{-1}$ in 2007. These were applied from 16 to 86 DAT at a rate of $1.33 \mathrm{~kg} \mathrm{ha}^{-1} \mathrm{~d}^{-1}$ in the first year, and from 25 to 86 DAT at a rate of $1.56 \mathrm{~kg} \mathrm{ha}^{-1} \mathrm{~d}^{-1}$ in the second. Due to the high soil potassium content (Table 1 ), this element was not applied. The total irrigation applied was $522 \mathrm{~mm}$ in the first year and $458 \mathrm{~mm}$ in the second. A regular program for disease and insect control was followed throughout the growing period, according to standard management practices.

\subsection{Plant sampling and analytical methods}

During the growing season, one plant of each elemental plot (four plants of each treatment) was randomly sampled at 34,41 , $48,55,62,69,76,83,90,97$ and 104 DAT in the first experiment, at $62,69,76,83,90,97$ and 104 DAT in the second and at 50,57,64, 71,78 and 85 DAT in the third. Leaves (blades and petioles), stems 
Table 2

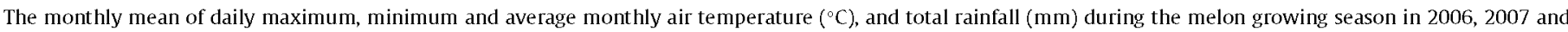
1981-2010 period.

\begin{tabular}{|c|c|c|c|c|c|c|c|c|c|c|c|c|}
\hline \multirow[t]{2}{*}{ Month } & \multicolumn{4}{|c|}{2006} & \multicolumn{4}{|c|}{2007} & \multicolumn{4}{|c|}{$1981-2010$} \\
\hline & Max. & Min. & Average & Rainfall & Max. & Min. & Average & Rainfall & Max. & Min. & Average & Rainfall \\
\hline May & 27.0 & 11.2 & 19.1 & 60.6 & 23.0 & 8.2 & 15.6 & 92.2 & 29.9 & 8.5 & 19.2 & 40.4 \\
\hline June & 32.1 & 14.2 & 23.2 & 23.4 & 28.8 & 11.7 & 20.3 & 20.0 & 30.2 & 13.3 & 21.8 & 20.8 \\
\hline July & 36.4 & 17.7 & 27.07 & 0 & 34.7 & 14.8 & 24.7 & 1.2 & 34.0 & 16.1 & 25.0 & 3.7 \\
\hline August & 34.2 & 16.2 & 25.2 & 12.2 & 34.3 & 15.4 & 24.8 & 3.3 & 34.0 & 16.0 & 25.0 & 4.4 \\
\hline September & 29.7 & 13.1 & 21.4 & 28.5 & 28.9 & 13.7 & 21.3 & 64.2 & 28.8 & 12.9 & 20.9 & 22.7 \\
\hline
\end{tabular}

and fruits (when present) were separated and weighed to obtain the fresh weights. Each plant organ was dried at $80^{\circ} \mathrm{C}$ to constant weight. The dry matter (DM), expressed as $\mathrm{g} \mathrm{m}^{-2}$, was calculated by dividing the dry weight of each organ by the ground area available for one plant $\left(2.25 \mathrm{~m}^{2}\right)$.

Sub-samples of DM of each plant part at each harvest were ground finely: the total $\mathrm{N}$ was measured by Kjeldahl's method and the ${ }^{15} \mathrm{~N}$ abundance was determined by Isotope Ratio Mass Spectrometry (IRMS) with a Mod.VG PRISM-II at the Stable Isotope Laboratory (Autonomous University of Madrid).

The harvests were carried out weekly and started at 63 and 67 DAT in 2006 and 2007, respectively. In the ripe fruits which were harvested prior to whole plant sampling, the values of DM and both $\mathrm{N}$ and ${ }^{15} \mathrm{~N}$ content were determined and later added to the values that the rest of fruits of the same plant had at the time of sampling. The percentage of ${ }^{15} \mathrm{~N}$ abundance was transformed into atom percentage ${ }^{15} \mathrm{~N}$ excess $\left({ }^{15} \mathrm{Nexc}\right.$ ) of the organ or fertiliser by subtracting the natural abundance $(0.3663$ at.\% $\mathrm{N})$ from the percentage ${ }^{15} \mathrm{~N}$ abundance of the organ or fertiliser.

${ }^{15} \mathrm{Nexc}=\left({ }^{15} \mathrm{Nc}-\delta^{15} \mathrm{~N}\right)$

where ${ }^{15} \mathrm{Nc}(\%)={ }^{15} \mathrm{~N}$ concentration in the organ or fertiliser. $\delta^{15} \mathrm{~N}$ $(\%)={ }^{15} \mathrm{~N}$ natural abundance.

Afterwards, the following calculations were performed using the procedure described by IAEA (2001). Considering the period between $t 1$ (time of the first application) and $t 2$ (time of the last application), the $\mathrm{N}$ concentration in each organ derived from the ${ }^{15} \mathrm{~N}$-labelled fertiliser in this period $\left(\mathrm{Ncdfef}_{(t 1-t 2)}\right)$, expressed as a percentage, was calculated using the equation:

$N c d f e f_{(t 1-t 2)}=\frac{{ }^{15} \text { Nexc }}{{ }^{15} \text { Nfexc }} \times 100$

where ${ }^{15} \mathrm{Nexc}(\%)={ }^{15} \mathrm{~N}$ excess in the organ. ${ }^{15} \mathrm{Nfexc}(\%)={ }^{15} \mathrm{~N}$ excess of the fertiliser.

The amount of $\mathrm{N}$ derived from the labelled fertiliser and taken up by the plant organs, expressed as $\mathrm{g} \mathrm{m}^{-2} \mathrm{Ndfe} f_{(t 1-t 2)}$, was calculated with the equation:

$N d f e f_{(t 1-t 2)}=\frac{N c d f e f_{(t 1-t 2)} \times \mathrm{DM}}{100}$

The total amount of $\mathrm{N}$ derived from fertiliser and taken up by the whole plant (Ndfef) was calculated as the sum of Ndfef for every above-ground organ of the plant.

After reaching the maximum content of $N d f e f(N d f e f m a x)$ in leaf and stem, the $\mathrm{N}$ translocation $\left(\mathrm{g} \mathrm{m}^{-2}\right)$ was determined from the Ndfefmax minus the content of Ndfef in the same organs at the time of plant sampling.

The percentage utilisation of fertiliser $\mathrm{N}$ applied between $t 1$ and t2 (FNU) was calculated as:

$F N U_{(t 1-t 2)}=\frac{N d f e f_{(t 1-t 2)}}{N a p_{(t 1-t 2)}} \times 100$

where $\operatorname{Nap}_{(t 1-t 2)}\left(\mathrm{g} \mathrm{m}^{-2}\right)=\mathrm{N}$ amount applied between $t 1$ and $t 2$.

\subsection{Statistical analysis}

Linear and quadratic regressions were performed using the statistical analysis software SPSS.

\section{Results}

\subsection{Dry matter}

Fig. 1 shows the linear adjustments of the leaf, stem, fruit and total aerial plant DM, with the standard errors, during the experimental period. The DM accumulation over the growing season was similar even though the experiments were carried out in different years. In the first experiment, the values of total aerial biomass were $31.8 \mathrm{~g} \mathrm{~m}^{-2}$ at 34 DAT. From this point, the plant DM increased linearly $(p<0.001)$ and the determination coefficients $\left(R^{2}\right)$ were 0.98 in the first two experiments and 0.97 in the third (Fig. 1d). The average rate of increase of the DM ranged between 12.1 and $13.4 \mathrm{~g} \mathrm{~m}^{-2} \mathrm{~d}^{-1}$. The lowest DM values, between 0.86 and $1.74 \mathrm{~g} \mathrm{~m}^{-2} \mathrm{~d}^{-1}$, corresponded to the stem (Fig. 1b), followed by the leaf which reached average rates close to $4.30-4.40 \mathrm{~g} \mathrm{~m}^{-2} \mathrm{~d}^{-1}$ in both experiments in 2006 and $2.86 \mathrm{~g} \mathrm{~m}^{-2} \mathrm{~d}^{-1}$ in 2007 (Fig. 1a). The fruit DM showed the highest growth rate, with values ranging between $6.69 \mathrm{~g} \mathrm{~m}^{-2} \mathrm{~d}^{-1}$, in the first experiment, and $8.35 \mathrm{~g} \mathrm{~m}^{-2} \mathrm{~d}^{-1}$, in the third (Fig. 1c).

\subsection{Nitrogen concentration}

At the start of the crop cycle in the first experiment, an increase in the leaf $\mathrm{N}$ concentration occurred and the highest value of $4.7 \%$ was observed at 41 DAT (Fig. 2a). The values decreased to $2.2 \%$ at 104 DAT. The leaf $\mathrm{N}$ concentrations in the second and third experiments were very similar and followed the same trend as in the first.

In the three experiments, the variations of the $\mathrm{N}$ concentration in the stem were similar. The highest $\mathrm{N}$ concentration in this organ was measured in the first samples which were taken at 34 and 50 DAT, first and third experiment, respectively (Fig. 2b). After that, the $\mathrm{N}$ concentration decreased until 55-64 DAT, when the values were close to $1.4 \%$. From then on, the $\mathrm{N}$ concentration changed little in the three experiments.

The fruit $\mathrm{N}$ concentration in experiment 1 was $3.5 \%$ at 41 DAT (Fig. 2c). Later, the values decreased to $1.8 \%$ at 69 DAT. From 76 DAT, the $\mathrm{N}$ concentration increased up to $2.9 \%$ at 104 DAT. The variations of the fruit $\mathrm{N}$ concentration were similar in the other two experiments, although in the third the values were slightly lower, with a minimum of $1.3 \%$ at 64 DAT.

\subsection{Nitrogen accumulation}

In all three experiments, the leaf $\mathrm{N}$ content over the growing season showed a significant fit to a second-degree polynomial function (Fig. 3a). The $\mathrm{N}$ content increased as the crop cycle advanced, especially in the two experiments in 2006, although the accumulation rate decreased progressively. 

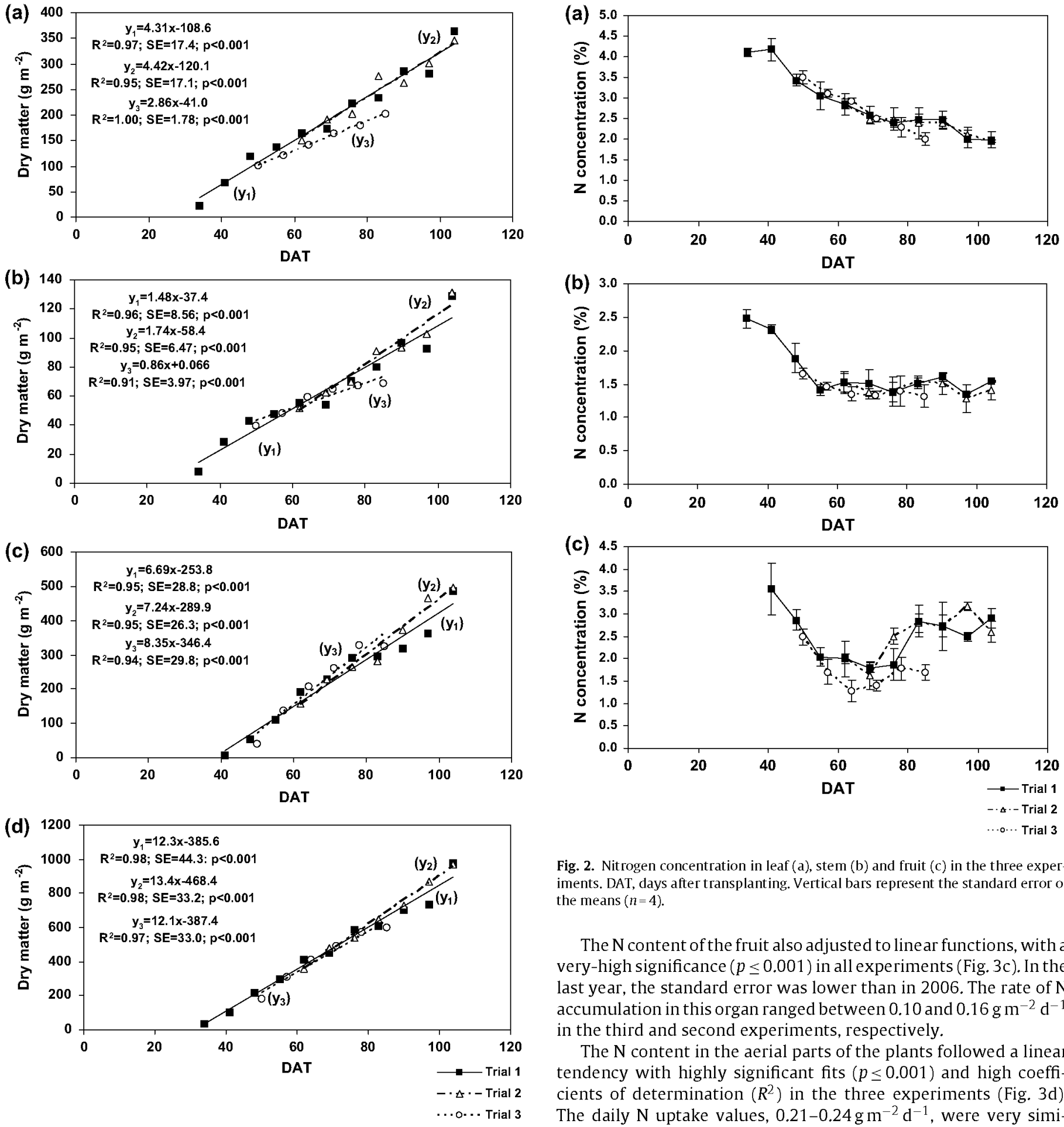

Fig. 2. Nitrogen concentration in leaf (a), stem (b) and fruit (c) in the three experiments. DAT, days after transplanting. Vertical bars represent the standard error of the means $(n=4)$.

The $\mathrm{N}$ content of the fruit also adjusted to linear functions, with a very-high significance ( $p \leq 0.001)$ in all experiments (Fig. 3c). In the last year, the standard error was lower than in 2006. The rate of $\mathrm{N}$ accumulation in this organ ranged between 0.10 and $0.16 \mathrm{~g} \mathrm{~m}^{-2} \mathrm{~d}^{-1}$ in the third and second experiments, respectively.

The $\mathrm{N}$ content in the aerial parts of the plants followed a linear tendency with highly significant fits $(p \leq 0.001)$ and high coefficients of determination $\left(R^{2}\right)$ in the three experiments (Fig. $3 \mathrm{~d}$ ). The daily $\mathrm{N}$ uptake values, $0.21-0.24 \mathrm{~g} \mathrm{~m}^{-2} \mathrm{~d}^{-1}$, were very similar in both experiments in 2006. The rate of $\mathrm{N}$ uptake was lower $\left(0.13 \mathrm{~g} \mathrm{~m}^{-2} \mathrm{~d}^{-1}\right)$ in the third experiment.

The fruits and leaves were the main sites of $\mathrm{N}$ accumulation in the plants, in all experiments. Until 93-95 DAT in 2006 and until 77 DAT in 2007, the $\mathrm{N}$ accumulation in the leaves was greater than in the fruits.

The N content of the stem over the growing cycle showed adjustments to linear functions which were highly significant $(p \leq 0.01)$ in the second experiment and very-highly significant $(p \leq 0.001)$ in the other two (Fig. 3b), with a higher determination coefficient $\left(R^{2}\right)$ and lower SE in the third one. The values were similar in the first two experiments, with a $\mathrm{N}$ uptake rate of $0.019 \mathrm{~g} \mathrm{~m}^{-2} \mathrm{~d}^{-1}$, higher than that in $2007\left(0.009 \mathrm{~g} \mathrm{~m}^{-2} \mathrm{~d}^{-1}\right)$.

\subsection{Nitrogen concentrations derived from ${ }^{15} \mathrm{~N}$-labelled fertiliser}

In the first experiment, by the last day of ${ }^{15} \mathrm{~N}$ application (34 DAT), the Ncdfef was $2.3 \%$ of the total $\mathrm{N}$ concentration in the leaves (Fig. 4a). In the other two experiments, the first increase of Ncdfef was recorded three days after finishing the ${ }^{15} \mathrm{~N}$ application (69 and 
(a)

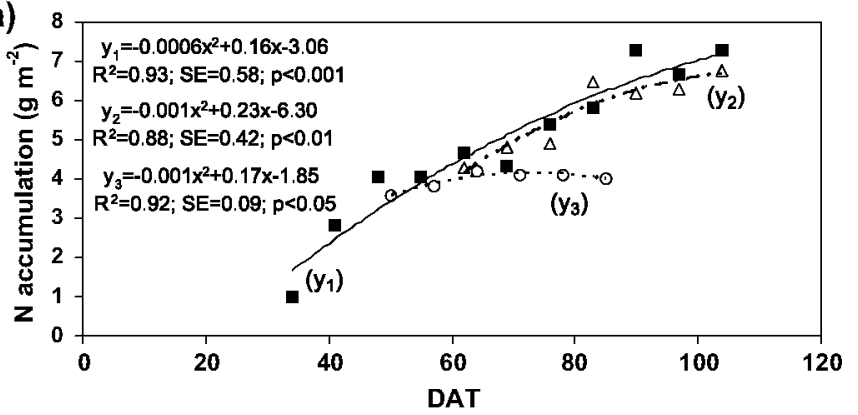

(b)
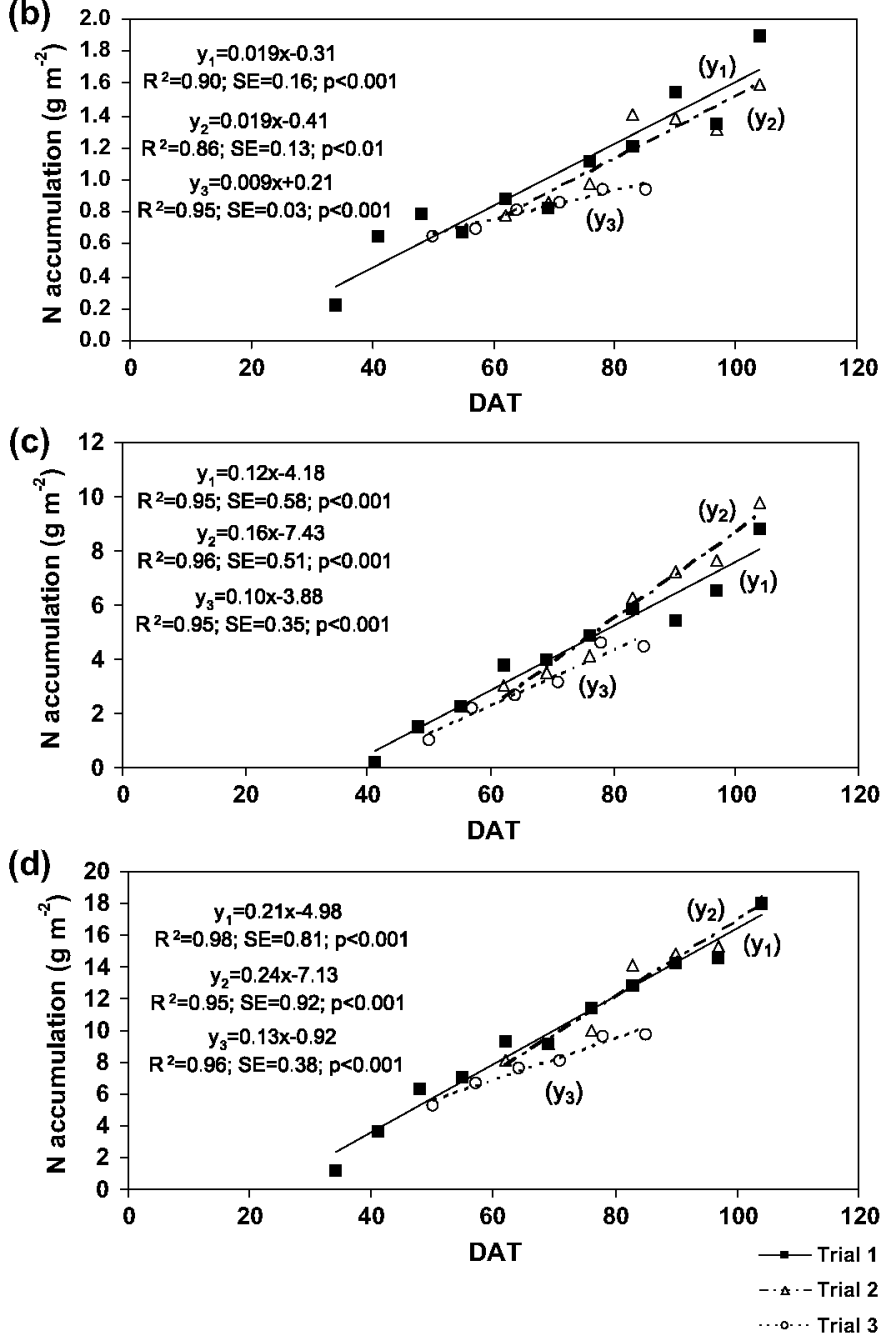

Fig. 3. Nitrogen accumulation in leaf (a), stem (b), fruit (c) and total aerial parts of the plant (d) in the three experiments. DAT, days after transplanting. Points represent means $(n=4)$. SE, standard error.

57 DAT, respectively). In experiment 1 , the highest $\mathrm{Ncdfef}$ occurred at 48 DAT, 14 days after the ${ }^{15} \mathrm{~N}$ application (DA ${ }^{15} \mathrm{NA}$ ), representing $6.8 \%$ of the total, although at $7 \mathrm{DA}^{15} \mathrm{NA}$, the value was already $6.6 \%$. Later, a continuous decrease was observed until the lowest value (1.7\%) was reached at 104 DAT. In the second experiment, the highest percentage was reached at $10 \mathrm{DA}^{15} \mathrm{NA}$ (76 DAT): $4.1 \%$, a value similar to that obtained at the same date in the first experiment. From then on, the percentages were similar in both experiments. In the third one, the highest ratio, $18.0 \%$ of the total, was also reached at $10 \mathrm{DA}^{15} \mathrm{NA}$ (64 DAT). Later, a decrease was observed and the lowest value (11.2\%) was at 85 DAT. In the stem (Fig. $4 \mathrm{~b}$ ), in all experiments, the Ncdfef was slightly higher than that of the leaf,
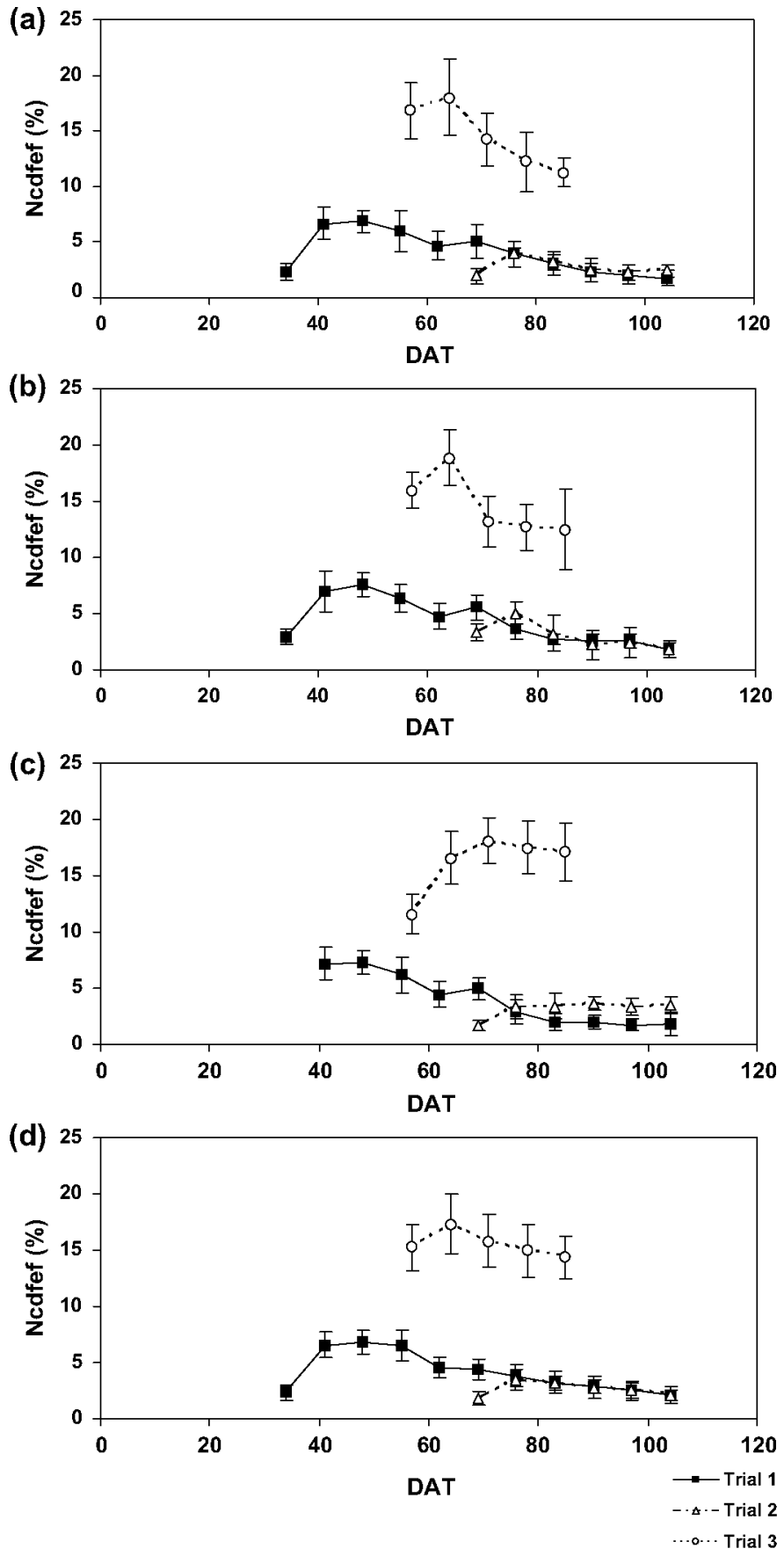

Fig. 4. Nitrogen concentration derived from labelled fertiliser (Ncdfef) in leaf (a), stem (b), fruit (c) and total aerial parts of the plant (d) in the three experiments. DAT, days aftertransplanting. Vertical bars represent the standard error of the means $(n=4)$.

with maximum value of $7.5 \%$ in the first experiment, $5.1 \%$ in the second and $18.9 \%$ in the third, which were reached at the same time.

In experiment 1 , in the fruit (Fig. 4c), a fast increase in Ncdfef was observed, with maximum values of $7.2 \%$ and $7.2 \%$ at 7 and 14 $\mathrm{DA}^{15} \mathrm{NA}$ (41 and $48 \mathrm{DAT}$ ), respectively. From this time, the values decreased to $2.0 \%$ at $49 \mathrm{DA}^{15} \mathrm{NA}$ (83 DAT) and then remained practically without variation until the end of the cycle. However, in the other two experiments, the tendency was different. In the second, the Ncdfef in the fruit increased quickly until $10 \mathrm{DA}^{15} \mathrm{NA}$ (76 DAT) with a value close to $3.3 \%$, remaining more or less stable over the 
rest of the cycle, while in the third the concentration increased quickly (to $16.6 \%$ ) until $10 \mathrm{DA}^{15} \mathrm{NA}$ (64 DAT). From this moment, little variation was recorded.

The Ncdfef in the plant aerial parts followed the same tendency as those of the leaf and stem (Fig. 4d). The highest values were $7.0 \%$, $3.95 \%$ and $17.5 \%$ in the first, second and third experiments, respectively. After that, these values declined to $2.2 \%, 2.5 \%$ and $14.4 \%$, respectively.

\subsection{Nitrogen accumulation derived from the ${ }^{15} \mathrm{~N}$-labelled fertiliser}

The Ndfef in the aerial parts followed the same tendency as the Ncdfef (Fig. 5a and b): a fast increase occurred for one or two weeks and then it decreased. In the leaf, the highest $N d f$ f $f$ value was observed at $14 \mathrm{DA}^{15} \mathrm{NA}$ in the first experiment, at $10 \mathrm{DA}{ }^{15} \mathrm{NA}$ in the second and at $10 \mathrm{DA}^{15} \mathrm{NA}$ in the third, with values of $0.27,0.20$ and $0.73 \mathrm{~g} \mathrm{~m}^{-2}$, respectively. In the stem, the highest Ndfef accumulation happened at the same time as in the leaf and the values were $0.06 \mathrm{~g} \mathrm{~m}^{-2}, 0.04 \mathrm{~g} \mathrm{~m}^{-2}$ and $0.15 \mathrm{~g} \mathrm{~m}^{-2}$ in the first, second and third experiments, respectively. In all experiments, the amount of $\mathrm{Ndfef}$ in the fruit increased over the course of the cycle, although the accumulation rate was higher during the first two or three weeks (Fig. 5c). At the end of the cycle, Ndfef was close to $0.25 \mathrm{~g} \mathrm{~m}^{-2}$ in the two experiments in 2006 and $0.88 \mathrm{~g} \mathrm{~m}^{-2}$ in 2007.

The uptake of Ndfef by the melon plants occurred until 14-17 DA ${ }^{15} \mathrm{NA}$ (Fig. 5d). After that, important variations were not observed. The maximum Ndfef uptake in the two experiments in 2006 was close to $0.45 \mathrm{~g} \mathrm{~m}^{-2}$ while in 2007 it was $1.45 \mathrm{~g} \mathrm{~m}^{-2}$.

The distribution in each organ of the $\mathrm{N}$ taken up varied, depending on the experiment. In the first (female-bloom stage), $60 \%$ of $\mathrm{N}$ uptake was in the leaf and $3 \%$ in the stem. In the second (at the end of fruit ripening) $44 \%$ of $\mathrm{N}$ uptake was in the leaf and $9 \%$ in the stem, while the values were $50 \%$ and $10 \%$, respectively, in the third experiment (in the middle of fruit growth).

\subsection{Translocation of nitrogen derived from the ${ }^{15} \mathrm{~N}$-labelled fertiliser}

The Ndfef translocation from the leaf, stem and vegetative parts of the plant to the fruit showed either a significant linear or seconddegree polynomial tendency in all experiments (Fig. 6a-c), with high determination coefficients.

From 48 DAT in the first experiment and from 76 DAT in the second (the dates with the highest values of Ndfef in the leaf and stem) until the end of the crop cycle (104 DAT), the translocation from the leaf to the fruit was 55\% in the first experiment and $30 \%$ in the second. The Ndfef translocation from the stem was $50 \%$ and $43 \%$ and from the total aerial vegetative parts $54 \%$ and $32 \%$ in the first and second experiments, respectively. In the third experiment, the rate of translocation from the leaf and from the vegetative parts of the plant to the fruit was higher than that in the two previous experiments. Thus, from 64 DAT (the date with the maximum content of Ndfef in the leaf and stem) to 85 DAT, the amount of Ndfef translocated from the leaf was $41 \%$, from the stem $34 \%$ and from the total vegetative aerial parts $40 \%$.

The functions of Ndfef translocation from the total vegetative aerial parts over the growing season (Fig. 6c) are relatively similar to those obtained for the leaf.At first, in the second and third experiments, the functions show a fast $\mathrm{N}$ translocation from the vegetative parts to the fruit, which decreased as time went on. However, for the first experiment, the function is linear and the $\mathrm{N}$ translocation did not decrease.

In all cases, Ndfef translocation started one or two weeks after its application.
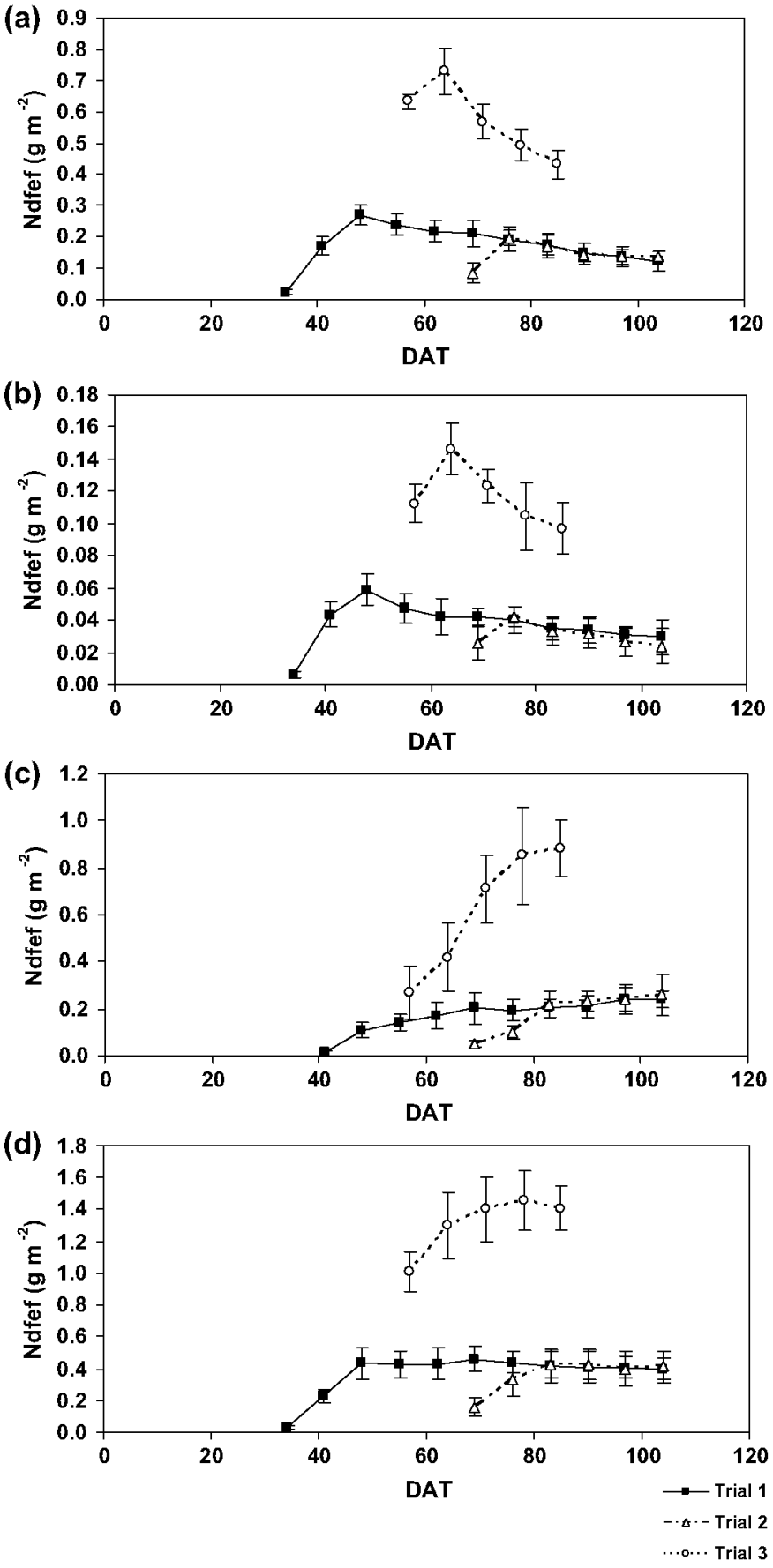

Fig. 5. Nitrogen accumulation derived from labelled fertiliser (Ndfef) in leaf(a), stem (b), fruit (c) and total aerial parts of the plant (d) in the three experiments. DAT, days after transplanting. Vertical bars represent the standard error of the means $(n=4)$.

If the Ndfef translocation is expressed as $\mathrm{mg} \mathrm{m}^{-2}$, the equations (Fig. $7 \mathrm{a}-\mathrm{c}$ ) have the same characteristics as those expressed in percentage, but in this case it can be seen that the leaf translocates much more $\mathrm{N}$ than the stem $(83 \%, 72 \%$ and $86 \%$ of the total Ndfef translocated in experiments 1,2 and 3, respectively).

\subsection{Fertiliser nitrogen utilisation}

The plants took up a large proportion of $\mathrm{N}$ during the first two weeks after its application (Fig. 8): from this time onwards, the $\mathrm{N}$ uptake was negligible. 
(a)

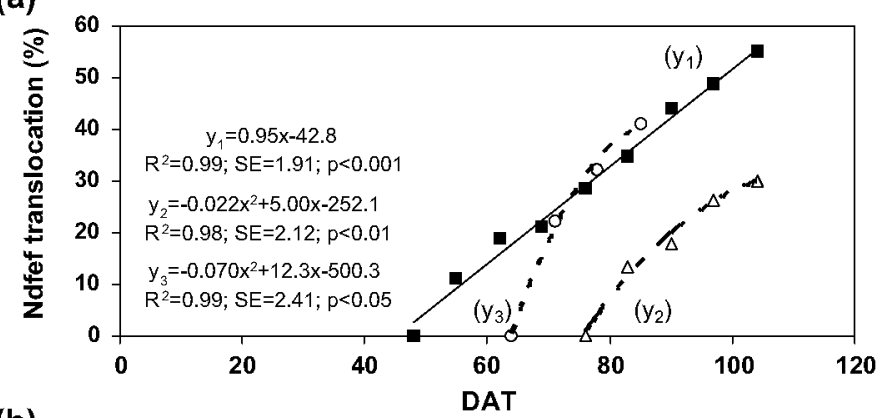

(b)

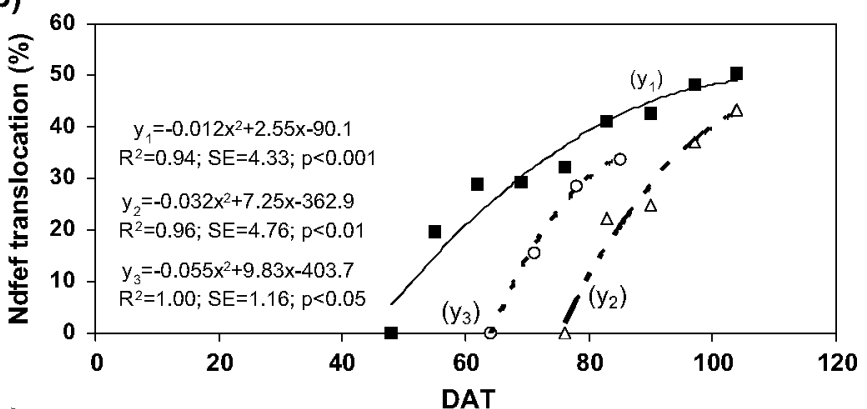

(c)

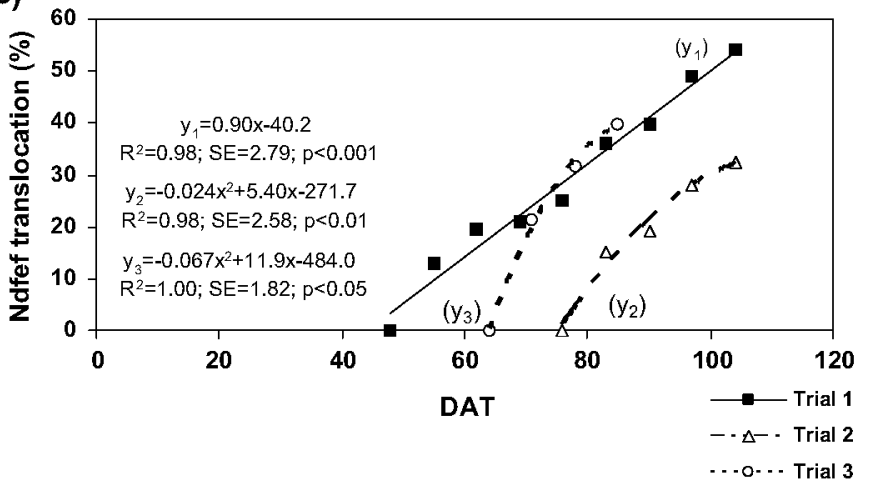

Fig. 6. Translocation of nitrogen derived from the labelled fertiliser (Ndfef), expressed as percentage, from the leaf (a), stem (b) and total vegetative aerial parts of the plant (c) to the fruit. DAT, days after transplanting. Points represent means $(n=4)$. SE, standard error.

In the first two experiments, the percentage utilisation of fertiliser $\mathrm{N}$ was similar - approximately $45 \%$ of the $\mathrm{N}$ applied - and in the third, it was close to $70 \%$.

\section{Discussion}

\subsection{Dry matter}

The growth dynamics observed in the three experiments were similar to those obtained in melon by Da Silva et al. (2006) and De Queiroz et al. (2008), with slow growth in the initial phase of the crop cycle followed by fast plant development. The values of aerial DM at 69 DAT ( $454.0 \mathrm{~g} \mathrm{~m}^{-2}$ ) were higher than $165.8 \mathrm{~g} \mathrm{~m}^{-2}$ obtained by Da Silva et al. (2006) and similar to $471.1 \mathrm{~g} \mathrm{~m}^{-2}$ reported by De Queiroz et al. (2008), for the same cultivar (Sancho). However, Da Silva et al. (2006) obtained at 69 DAT a ratio of biomass between the fruit and aerial vegetative parts of $42 / 58$. In our case the ratios were 52/48 (first and third experiments) and 49/51 (experiment 2).

An appropriate balance between the vegetative parts, which mainly act as a source of assimilates, and the reproductive parts, primarily sink organs, is clearly of great importance for optimal crop (a)

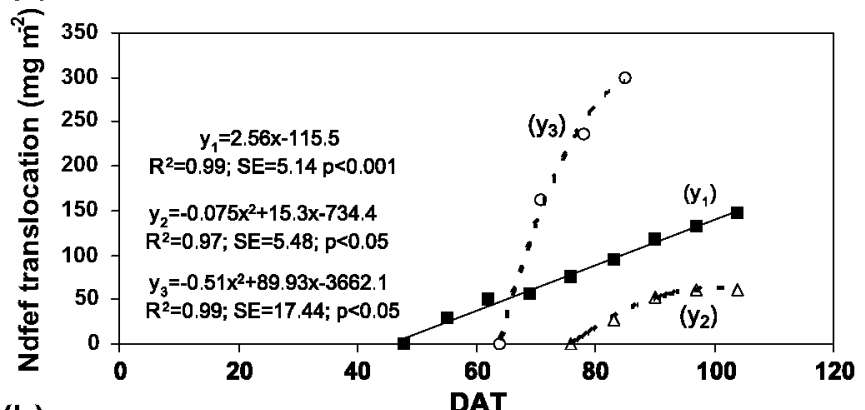

(b)

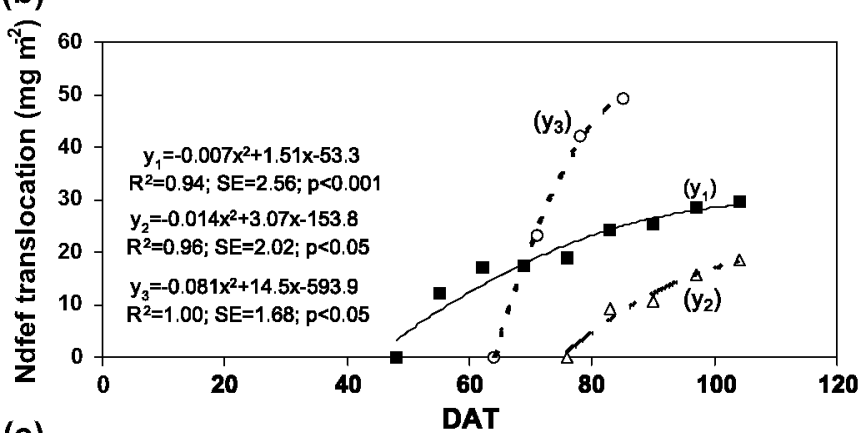

(c)

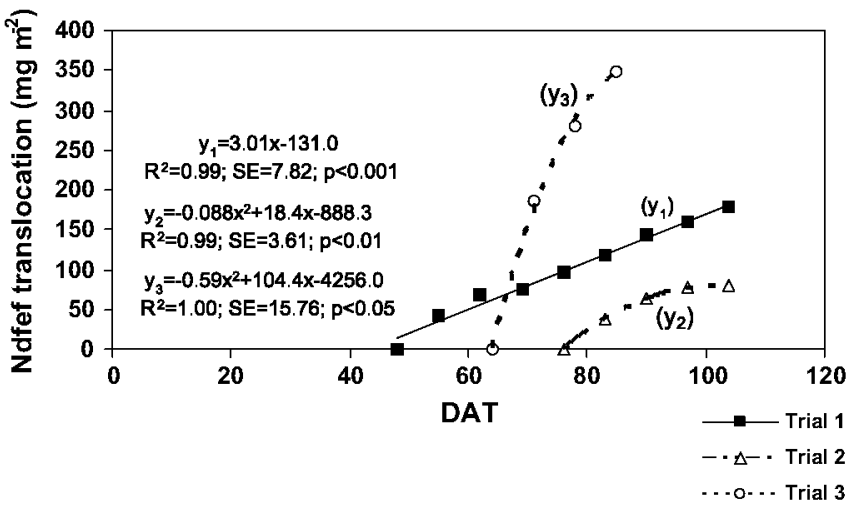

Fig. 7. Translocation of Ndfef (nitrogen derived from the labelled fertiliser) expressed as $\mathrm{mg} \mathrm{m}^{-2}$, from the leaf (a), stem (b) and total vegetative aerial parts of the plant (c) to the fruit. DAT, days after transplanting. Points represent means $(n=4)$. SE, standard error.

production (Peil and Galvez, 2005), because an excessive amount of vegetative biomass, in relation to the reproductive, often indicates a nutritional imbalance in which $\mathrm{N}$ plays an important part (Hartz and Hochmuth, 1996; Mohammad, 2004).

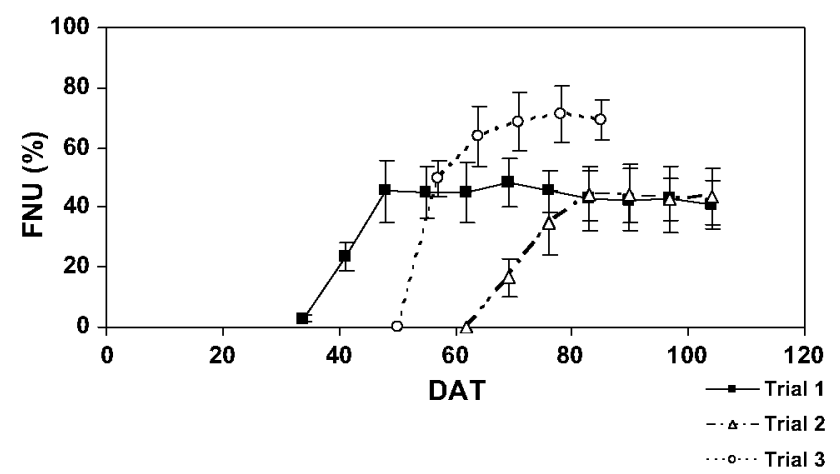

Fig. 8. Utilisation of fertiliser nitrogen $(F N U)$ in the three experiments. DAT, days after transplanting. Vertical bars represent the standard error of the means $(n=4)$. 
Taking into account this fact and the level of development reached by the plants, it follows that the crop did not suffer a deficit of $\mathrm{N}$ at any time (Castellanos et al., 2010).

\subsection{Nitrogen concentration}

The $\mathrm{N}$ concentration at the end of the crop cycle was lower than that obtained by Kirnak et al. (2005) in cv. Polidor $(7.65 \%$ with $120 \mathrm{~kg} \mathrm{Nha}^{-1}$ ) and slightly lower than those found by Panagiotopoulos (2001) in cv. Dichty (2.5-3.6\%).

The $\mathrm{N}$ concentration in the vegetative parts decreased from 34-42 dAT onwards as a result of both fast vegetative growth "law of progressive decline" (Le Bot et al., 1998) - and N translocation from the vegetative parts to the fruit. After muskmelon fruit set, the other organs of the plant, especially the leaves, function as a source of $\mathrm{N}$ for the fruits (Fukutoku et al., 2000).

The fruit $\mathrm{N}$ concentration decreased until 64-69 DAT, the period when the harvests started. So, the concentration increased due to the higher $\mathrm{N}$ percentage in immature fruits in relation to mature fruits, in accordance with the results obtained by Darawsheh and Bouranis (2006), who stated that the fruit load has a notable effect on the $\mathrm{N}$ status. They found, in experiments with tomato, that the extractable $\mathrm{N}$ concentration was increased greatly when more fruits were ripening.

\subsection{Nitrogen accumulation}

The rate of $\mathrm{N}$ accumulation in the whole plant $\left(0.13 \mathrm{~g} \mathrm{~m}^{-2} \mathrm{~d}^{-1}\right)$ in the third experiment (2007) was lower than that observed in both experiments in 2006. It could be due to a higher soil mineral $\mathrm{N}$ content before transplanting in the first year $\left(67 \mathrm{~kg} \mathrm{~N} \mathrm{ha}^{-1}\right)$ than in the second ( $34 \mathrm{~kg} \mathrm{~N} \mathrm{ha}^{-1}$ ) (Castellanos et al., 2010), because the amount of nitrate in soil regulates the uptake of $\mathrm{N}$ by crops (Gastal and Lemaire, 2002). On the other hand, the fact that the fruit $\mathrm{N}$ uptake in all experiments was similar, and both leaf and stem $\mathrm{N}$ uptake were lower, suggests that when the plant takes up less $\mathrm{N}$, this reduction is first observed in the leaves and stem because the fruits are a strong sink and there is translocation to them from vegetative parts, mainly from the leaves (Atta et al., 2004). The patterns of $\mathrm{N}$ accumulation during the growing period for the whole plant and individual plant parts essentially followed the time course of the DM production, as shown also by Latus et al. (1995) in cucumber.

Like the growth, $\mathrm{N}$ uptake was slow during the vegetative stage but increased greatly at the beginning of the reproductive period, before slowing down again at the end of the crop cycle. The N-uptake rate of crops is regulated not only by soil mineral $\mathrm{N}$ availability but also by the crop growth rate. The $\mathrm{N}$ uptake per unit biomass decreases as crop mass increases, suggesting that the relationship between $\mathrm{N}$ uptake and growth is complex (Gastal and Lemaire, 2002).

The increases in the leaf $\mathrm{N}$ content were the result of the increase in the leaf biomass (more marked in 2006 than in 2007), which counteracted and exceeded the continuous decrease in the $\mathrm{N}$ concentration. As in the leaf, the increase in the stem $\mathrm{N}$ content was due to the increase in biomass, since the $\mathrm{N}$ concentration remained more or less constant from 55 DAT in the three experiments.

\subsection{Nitrogen concentrations derived from the ${ }^{15} \mathrm{~N}$-labelled fertiliser}

The results show that $\mathrm{N}$ derived from the labelled fertiliser started to be taken up immediately after being applied and its concentration followed the same trend in the leaf and stem. There was a fast increase in the proportion of Ncdfef until 10 days after the start of its application. Later, as the labelled fertiliser decreased in the soil, because it has been taken up by the plants, fixed in the soil or lost by leaching, the uptake decreased as the plants took up non-labelled fertiliser - which was applied throughout the rest of the vegetative cycle. In 2006, the two experiments had similar Ncdfef values, independent of the application time. However, in the third experiment, in 2007, the values were much higher because the amount of labelled fertiliser was also higher.

The percentage of fruit $\mathrm{N}$ derived from labelled fertiliser was higher in the second experiment than in the first, because the application was made in the last days of fruit ripening. During this stage, uptake of $\mathrm{N}$ by the fruits was greater, in accordance with the results obtained by Latus et al. (1995) in cucumber.

\subsection{Nitrogen accumulation derived from the ${ }^{15} \mathrm{~N}$-labelled fertiliser}

The $\mathrm{N}$ uptake derived from labelled fertiliser increased in the vegetative parts of the plants for about two weeks and then decreased as a result of $\mathrm{N}$ translocation to the fruits, which are a strong sink whereas the vegetative parts (leaves and stem) act as a source of N, according to Fukutoku et al. (2000).

The fact that the amount of $\mathrm{N}$ derived from fertiliser increased in the whole plant for two weeks and then did not change significantly suggests that $\mathrm{N}$, independent of the application time, was available to the plants during this period but they could not take up $\mathrm{N}$ more than two weeks after its application, because it had been either leached or immobilized in the soil.

The $\mathrm{N}$ distribution in the different plant organs depended on the phenological phase of the vegetative cycle in which $\mathrm{N}$ was taken up. The $\mathrm{N}$ derived from labelled fertiliser applied during female bloom or during the first stage of fruit growth accounted for $75 \%$ of the total $\mathrm{N}$ uptake and was distributed mainly in the vegetative parts of the plant. In contrast, for $\mathrm{N}$ derived from the fertiliser applied later, there was an increased $\mathrm{N}$ percentage in the reproductive parts. This is due to the sink effect of the fruits, so that the more fruits there are, the greater is the amount of $\mathrm{N}$ directed to them. This effect has been observed also by Atta et al. (2004) in pea (Pisum sativum L.), Darawsheh and Bouranis (2006) in tomato (Lycopersicon esculentum Mill) and Mohammad (2004) in squash (Cucurbita pepo L.).

\subsection{Nitrogen translocation derived from the ${ }^{15} \mathrm{~N}$-labelled fertiliser}

The dynamics of $\mathrm{N}$ accumulation and translocation within the plant can be gauged from the changing pattern of source and sink interactions (Atta et al., 2004). In agreement with the findings of Atta et al. (2004), when our melon plants had vegetative but not reproductive growth, the $\mathrm{N}$ accumulated mainly in the leaves. As the fruits started to develop and grow, their higher N demand, relative to the vegetative organs, caused a continuous translocation of $\mathrm{N}$ from the stems and, particularly, the leaves.

In the first experiment, $\mathrm{N}$ derived from labelled fertiliser started to be translocated at 48 DAT, when the fruit DM was still low (54.7 $\mathrm{g} \mathrm{m}^{-2}$ ) and $\mathrm{N}$ translocation was moderate, but it continued during the cycle almost linearly, although with a slight tendency to slow down. By contrast, in the second and third experiments, there was a fast translocation 10 days after completing the fertiliser application and as the cycle progressed the percentage of $\mathrm{N}$ translocated was decreasing. This is in agreement with the findings of FangGong et al.(2002), who stated that newly taken-up N is translocated more easily.

The $\mathrm{N}$ translocation from the leaf, stem and vegetative parts to the fruit decreased progressively when the $\mathrm{N}$ was applied in more-advanced stages of the vegetative cycle. Atta et al. (2004) reported important differences according to the time of $\mathrm{N}$ applica- 
tion, although their results for pea plants differed from ours because the application time was different (from the 7-leaf stage to the beginning of seed filling). The percentage of $\mathrm{N}$ translocated to the fruit was in agreement with that reported by Fukutoku et al.(2000), who found that nearly $50 \%$ of the fruit $\mathrm{N}$ at harvest was derived from the redistribution of $\mathrm{N}$ from other organs, while in our case it ranged between $72 \%$ of the Ndfef in the fruit when N was applied at flowering and 31\% when it was applied at the end of fruit ripening; and, as in our case, the leaf was the main source of N. Even though in the first experiment (2006) the ${ }^{15} \mathrm{~N}$ was applied in a previous phenological stage, the amounts of Ndfef translocated in 2007 were much higher, because Ndfef accumulated in the vegetative part was also much higher as a result of the different amount of labelled fertiliser supplied in each year.

\subsection{Fertiliser nitrogen utilisation}

The percentage utilisation of fertiliser $\mathrm{N}$ in the first and second experiments was different in comparison with the third, probably because in 2006 the soil mineral $\mathrm{N}$ content was higher (Castellanos et al., 2010): according to the results obtained in different crops such as tomato (Halitligil et al., 2002; Zuraiqui et al., 2002), pepper (Capsicum annuum L.), cucumber and melon (Halitligil et al., 2002), the greater the amount of $\mathrm{N}$ fertiliser in the soil, the lower the utilisation rate.

The percentage utilisation of fertiliser $\mathrm{N}$ was higher than that obtained by Halitligil et al. (2002) in melon (32.9\%) or by Kotur et al. (2007) in tomato (9-23\%) and was similar to that reported by Kotur et al. (2007) in French bean (Phaseolus vulgaris L.) (30-64\%) and by Atallah et al. (2002), Halitligil et al. (2002) and Latus et al. (1995) in cucumber $(55-70 \%, 40-61 \%$ and $59 \%$, respectively). The high variability of these results shows that the percentage $\mathrm{N}$ fertiliser use depends not only on the crop but also the conditions under which it grows, and does not seem to be affected by the time of fertiliser application.

\section{Conclusions}

The amount of $\mathrm{N}$ taken up by the aerial parts of the plant was not affected by the application time, from flowering (50\% plants with perfect flowers) to the first harvest. However, the time of fertiliser application influenced the amount of $\mathrm{N}$ translocated from the vegetative parts to the fruit. So, when the fertiliser was applied later, the Ndfef translocation decreased: from $54 \%$ when N was applied at female flowering to $32 \%$ when it was applied at the end of fruit ripening. The $\mathrm{N}$ translocated from the leaves to the fruit represented approximately $85 \%$ of the total $\mathrm{N}$ translocation when the $\mathrm{N}$ was applied at female flowering and at the mid-point of fruit growth. When the $\mathrm{N}$ was applied at the end of fruit ripening, this value was lower (72\%). The $\mathrm{N}$ fertiliser was available for between 2 and 2.5 weeks after its application through fertigation, independent of the application time between female flowering and the final stage of fruit ripening. The daily amount of $\mathrm{N}$ uptake by the plant showed a linear trend suggesting that the melon crop could be fertilised with constant daily $\mathrm{N}$ amounts until $2-3$ weeks before the final harvest.

\section{Acknowledgments}

We thank Dr. Ramón Redondo (Faculty of Sciences of the Autonomous University of Madrid) for analysis of the ${ }^{15} \mathrm{~N}$ in the plant material. This work was funded by the Instituto Nacional de Investigación y Tecnología Agraria y Alimentaria, Spanish Agency (Project RTA 04-111-C3).

\section{References}

Atallah, T., Darwish, T., El Moujabber, M., 2002. Modality of fertigation of protected cucumber and nitrogen use efficiency under field conditions. In: IAEA (Ed.), Water Balance and Fertigation for Crop Improvement in West Asia. IAEA TECDOC-1266, Vienna, pp. 41-48.

Atta, S., Maltese, S., Marget, P., Cousin, R., 2004. ${ }^{15} \mathrm{NO}_{3}$ assimilation by the field pea Pisum sativum L. Agronomie 24, 85-92.

Baker, J.K., Leskovar, D.I., Reddy, V.R., Dainello, F.J., 2001. A simple phenological model of muskmelon development. Ann. Bot. 87, 615-621.

Cabello, M.J., Castellanos, M.T., Romojaro, F., Martínez, C., Ribas, F., 2009. Yield and quality of melon grown under different irrigation and nitrogen rates. Agric Water Manage. 96, 866-874.

Castellanos, M.T., Cartagena, M.C., Ribas, F., Cabello, M.J., Arce, A., Tarquis, A.M., 2010. Efficiency indexes for melon crop optimization. Agron. J. 102, $716-722$

Castellanos, M.T., Cabello, M.J., Cartagena, M.C., Tarquis, A.M., Arce, A., Ribas, F., 2011. Growth dynamics and yield of melon as influenced by nitrogen fertilizer. Sci. Agric. 68, 131-261.

DaSilva, M.J., De Medeiros, J.F., De Oliveira, F.H.T., Dutra, I., 2006. Dry matter accumulation and nutrient uptake by pele de sapo melon plants. Rev. Bras. Engenharia Agr. Amb. 10, 364-368.

Darawsheh, M.K., Bouranis, D.L., 2006. Season-dependent fruit loading: effect on dry mass, water, and nitrogen allocation in tomato plants. J. Plant Nutr. 29 $347-359$

De Queiroz, H.V., De Queiroz, F., De Medeiros, J.F., Dutra, I., Queiroz, R.F., 2008. Growth of the melon plants under different irrigation depths and levels of nitrogen and potassium. Rev. Caatinga 21, 174-178.

Fagan, E.B., Medeiros, S.L.P., Simon, J., Lopes da Luz, G., Borcioni, E., Jasniewicz, L.R., Casaroli, D., Augusto, P., 2006. Evolução e partição de fitomassa seca do meloeiro em hidroponía. Acta Sci. Agron. 28, 165-172.

FangGong, S., YunHua, W., YuanXi, Y., Wunimuren, Inanaga, S., 2002. Distribution dynamics of nitrogen in the organs of sweet pepper (Capsicum ammum L.) at early flowering stage. Acta Hort. 29, 238-242.

FAOSTAT, 2010. Available at: http://faostat.fao.org/site/567/DesktopDefault.aspx? PagelD $=567$ (verified 15.12.10). FAO, Roma.

Fontes, P.C.R., Coelho, E.L, Cardoso, A.A., 2003. Petiole sap nitrate and leaf nitrogen critical values in melon plants grown in unheated greenhouse and field conditions. J. Plant Nutr. 26, 1403-1411.

Fukutoku, Y., Teraoka, T., Koto, S., Kubo, K., 2000. Nitrogen absorption and distribution of muskmelons (Cucumis melo L.) at different growth stages using hydroponics. Jpn. J. Soil Sci. Plant Nutr. 71, 72-81.

Gastal, F., Lemaire, G., 2002. N uptake and distribution in crops: an agronomical and ecophysiological perspective. J. Exp. Bot. 53, 789-799.

Halitligil, M.B., Akin, A.i., Kislai, H., Ozturk, A., Deviren, A., 2002. Yield, nitrogen uptake and nitrogen use efficiency by tomato, pepper, cucumber, melon and eggplant as affected by nitrogen rates applied with drip-irrigation under greenhouse conditions. In: IAEA (Ed.), Water Balance and Fertigation for Crop Improvement in West Asia. IAEA-TECDOC-1266, Vienna, pp. 99-110.

Hartz, T.K., Hochmuth, G.J., 1996. Fertility management of drip-irrigated vegetables. HortTech. 6, 168-172.

IAEA, 2001. Use of Isotope and Radiation Methods in Soil and Water Management and Crop Nutrition. Manual. Internat ional Atomic Energy Agency, Vienna.

Janat, M., 2007. Efficiency of nitrogen fertilizer for potato under fertigation utilizing a nitrogen tracer technique. Commun. Soil Sci. Plant Anal. 17 (18), $2401-2422$.

Kirnak, H., Higgs, D., Kaya, C., Tas, I., 2005. Effects of irrigation and nitrogen rates on growth, yield, and quality of muskmelon in semiarid regions. J. Plant Nutr. 28 , $621-638$.

Kotur, S.C., Shilpashree, Y.P., Sheshshayee, M.S., Ramesh, P.R., 2007. Nitrogen use efficiency in tomato (Lycopersicon esculentum L.) and French bean (Phaseolus vulgaris, L.) as influenced by coating of urea with neem oil and graded levels of nitrogen. J. Hort. Sci. 2, 119-122.

Latus, C., Merbarch, W., Makswitat, E., Augustin, J., Ruppel, S., Kuchenbuch, R., 1995. ${ }^{15} \mathrm{~N}$-dynamics of cucumber (Cucumis sativus L.) in field trials on sandy loam in Brandenburg (Germany). Isotopes Environ. Health Stud. 31 (3-4), 357-362.

Le Bot, J., Adamowicz, S., Robin, P., 1998. Modelling plant nutrition of horticultural crops: a review. Sci. Hort. 74, 47-82.

Lopez-Bellido, L., Lopez-Bellido, R.J., Lopez-Bellido, F.J., 2006. Fertilizer nitrogen efficiency in durum wheat under rainfed Mediterranean conditions: effect of split application. Agron. J. 98, 55-62.

MARM, 2010. Anuario de estadistica agroalimentaria y pesquera 2009. Available at: http://www.mapa.es/es/estadistica/pags/anuario/2009/indice.asp?parte $=38$ capitulo=13\&grupo=6\&seccion=18 (verified 15.12 .10 ).

Mohammad, M.J., 2004. Squash yield, nut rient content and soil fertility parameters in response to methods of fertilizer application and rates of nitrogen fertigation. Nutr. Cycl. Agroecosyst. 68, 99-108.

Panagiotopoulos, L., 2001. Effects of nitrogen fertigation on growth, yield, quality and leaf nutrient composition of melon (Cucumis melo L.). Acta Hort. 563, $115-121$.

Peil, R.M., Galvez, J.L., 2005. Reparto de materia seca como factor determinante de la producción de las hortalizas de fruto cultivadas en invernadero. Rev. Bras. Agrociência 1, 5-11. 
Purqueiro, L.F.V., Cecílio Filho, A.B., Barbosa, J.C., 2003. Efeito da concentraçao de nitrôgenio na soluçao nutritiva e do número de frutos por planta sobre a produçao do meloeiro. Hort. Bras. 21, 185-190.

Scholberg, J., McNeal, B.L., Boote, K.J., Jones, J.W., Locascio, S.J., Olson, S.M., 2000. Nitrogen stress effects on growth and nitrogen accumulation by field-grown tomato. Agron. J. 92, 159-167.

Soil Survey Staff, 1999. Soil Taxonomy: A Basic System of Soil Classification for Making and Interpreting Soil Surveys, 2nd ed. USDA-SCS Agric. Handb. 436. U.S. Gov. Print Office, Washington, DC.
Tanemura, R., Kurashima, H., Ohtake, N., Sueyoshi, K., Ohyama, T., 2008. Absorption and translocation of nitrogen in cucumber (Cucumis sativis $\mathrm{L}$.) plants using the ${ }^{15} \mathrm{~N}$ tracer technique. Soil Sci. Plant Nutr. 54, 108-117.

Zuraiqui, S., Qawasmi, W., Deek, I., Mohammad, M.J., 2002. Management of nitrogen fertigation of tomato with the use of ${ }^{15} \mathrm{~N}$ technology. In: IAEA (Ed.), Water Balance and Fertigation for Crop Improvement in West Asia. IAEA-TECDOC-1266, Vienna, pp. 27-40. 